九州大学学術情報リポジトリ

Kyushu University Institutional Repository

\title{
SYNONYMIC NOTES ON SOME JAPANESE WEEVILS OF THE FAMILIES ATTELABIDAE AND CURCULIONIDAE
}

Morimoto, Katsura

Entomological Laboratory, Faculty of Agriculture, Kyushu University

https://doi.org/10.5109/2434

出版情報: ESAKIA. 20，pp.54-54，1983-12-15. Entomological Laboratory，Faculty of Agriculture， Kyushu University

バージョン :

権利関係 : 
ESAKIA, (20):54.1983

\title{
SYNONYMIC NOTES ON SOME JAPANESE WEEVILS OF THE FAMILIES ATTELABIDAE AND CURCULIONIDAE
}

\author{
Katsura Morimoto
}

1. Depasophilus pacatoides Voss, 1937 is synonymous with Deporaus minimus Kôno, 1928. The syntypes of $D$. pacatoides in the British Museum (Natural History) are teneral individuals of $D$. minimus with weakly shrunk abdomen.

2. The record of Rhynchites conicus Illigar from Japan by Sharp (1889) is erroneous due to misidentification of Involvulus cylindricus Schilsky, 1920.

3. Macrocorynus viridulus (Roelofs, 1873) should be transferred to Cyphicerus. Cyphicerus aceri Kôno, 1930 (=tosanus Kôno, 1930) is synonymous with viridulus. The named species were originally described in Myllocerus.

4. Myllocerus dissimilis Voss, 1939 is a synonym of Myllocerus naso Sharp, 1896. I have examined a specimen (syntype ?) of dissimilis in the Koenig $\mathrm{Mu}-$ seum, Bonn, which is a greyish form of naso, and f. trifasciata Voss, 1939 is probably a typical colour form of the latter.

5. Miarus atricolor new name for Miarus vestitus Kôno, 1930 (nec Roelofs, 1875), Ins. Mats., IV: 147, and Morimoto (nec Roelofs, 1875), Kontyû, 27 : 190, 1959.

6. Miarus minimus Morimoto, 1959 is synonymous with Miarus vestitus Roelofs, 1875. The types were compared.

7. Rhytidosomus holdhausi Wagner, 1944 is synonymous with Scleropteroides hypocrita(Hustache, 1916). The latter was originally described in Ceuthorrhynchidius.

8. Pseudorhyssematus Morimoto, 1962 is synonymous with Phrissoderes Marshall, 1948. Phrissoderes rufitarsis (Roelofs, 1875), comb. nov. from Pseudorhyssematus.

9. Didothis Zaslavski, 1956 is synonymous with Paracythopeus Heller, 1940. Paracythopeus melancholicus (Roelofs, 1875), comb. nov. from Didothis.

10. Orsophagus Roelofs, 1874 placed in the Erirhininae is synonymous with Acalyptus Schoenherr, 1836. Acalyptus trifasciatus (Roelofs, 1874), comb. nov. from Orsophagus.

11. Sphinxioides Voss et Chûjô̂, 1960 and Epidemimaea Chûjồ et Voss, 1960, as a subgenus of Demimaea, are synonymous with Sphinxus Roelofs, 1875. Roelofs stated in the original description of Sphinxus as "Ecusson nul", but the type specimen of Sphinxus pubescens Roelofs, 1875, the type of the genus, has an evident scutellum. Sphinxus koikei (Voss et Chûjô, 1960), comb. nov. from Sphinxioides. Sphinxus ihai (Chûjồ et Voss, 1960), comb. nov. from Demimaea (Epidemimaea). 